\title{
Determination of nitrogen pollution amount from livestock breeding in Turkey
}

\author{
Türkiye'de hayvancılık faaliyetlerinden kaynaklanan azot kirliliği miktarının belirlenmesi
}

\author{
Büşra YAYLI*1,a, ílker KILIÇ⿻, \\ ${ }^{1}$ Bursa Uludag Üniversity, Faculty of Agriculture, Deparment of Biosystems Engineering, 16059, Bursa
}

• Geliş tarihi / Received: $21.04 .2021 \quad$ •Düzeltilerek geliş tarihi / Received in revised form: $20.08 .2021 \quad$ • Kabul tarihi / Accepted: 04.09.2021

\begin{abstract}
Nitrogen $(\mathrm{N})$ pollution is gradually increasing from agriculture production. Nitrogen pollution derived from agriculture has important components using overuse chemical fertilizers, excess amount formation of manure and incorrect manure management systems etc. Nitrogen compounds that take up with the soil, water and air with the nitrogen cycle cause various environmental problems. It is a critical issue that needs to be studied on, as the efficiency and production decrease will be encountered by decreasing the nitrogen rate in reducing nitrogen pollution. In this paper, the estimation of nitrogen pollution derived from livestock production in Turkey and aimed need to focus points to be considered. The nitrogen pollution load created by farm animals in 2019 is 1062004 tons N/year and 834381 tons N/year in 2020 in Turkey. Cattle are the animal species that have the greatest effect on nitrogen excretion. Because the daily manure production amounts are higher than other types, and the moisture content is high. Therefore, processing and control are more difficult than other species. The integrated approach is needed to reduce elementary nitrogen formation due to the gradual formation of nitrogen from agricultural systems and intensive agriculture areas.
\end{abstract}

Keywords: Livestock animal, Manure, Nitrogen

$\ddot{O} z$

Tarımsal üretimden kaynaklanan azot (N) kirliliği giderek artmaktadır. Tarımda azot kirliliğinin en önemli bileşenleri; kimyasal gübre kullanımı, doğal gübre oluşumu ile yanlış gübre yönetim sistemleridir. Azot döngüsü ile toprağa, suya ve havaya karışan azot bileşikleri çeşitli çevresel problemlere neden olmaktadır. Azot kirliliğinin azaltılmasında azot oranının düşürülmesiyle verim ve üretim düşüşüyle karşllaşılacağından üzerinde durulması gerekilen kritik bir konudur. Bu çalışmada, Türkiye'deki çiftlik hayvanlarından kaynaklanan gübre üretiminin neden olduğu azot kirliliği boyutunun belirlenmesi ve üzerinde durulması gereken noktaların ortaya konulması hedeflenmiştir. Türkiye'de 2019 yılında çiftlik hayvanlarının oluşturduğu azot kirlilik yükü 1062004 ton N/yıl iken 2020 yılında 834381 ton N/yıl'dır. Azot atılımına en büyük etkide bulunan hayvan türü büyükbaş hayvanlardır. Çünkü günlük olarak gübre üretim miktarlarl diğer türlere göre daha fazladır ve nem içeriği yüksektir. Bundan dolay işlenmesi ve kontrol altına alınması diğer türlere göre daha zor olmaktadır. Tarımsal sistemlerden ve yoğun tarım uygulanan alanlardan kaynaklanan azotun kademeli oluşması nedeniyle, elementer azot oluşumunun azaltılması için entegre bir yaklaşıma ihtiyaç bulunmaktadır.

Keywords: Çiftlik hayvani, Gübre, Azot

\footnotetext{
*a Büşra YAYLI; busrayayli@uludag.edu.tr, Tel: (0534) 65624 70, orcid.org/0000-0002-0198-3550

${ }^{\mathrm{b}}$ orcid.org/0000-0003-0087-6718
} 


\section{Introduction}

Nitrogen pollution is on the way to becoming one of the most dangerous environmental problems in the world. Nitrogen pollution's the main source of in the world is the agricultural sector. Main sources of agricultural nitrogen pollution; excessive use of chemical fertilizers and not managing fertilizer and waste management systems correctly (Günal, 2019). It is possible to reduce the harmful effects caused by nitrogen by reducing the application of chemical fertilizers with nitrogen and reducing the feed protein content in animals. However, food production, efficiency and global food security should not be compromised. Although this problem is not sufficiently emphasized, it does not seem easy to develop and implement a nitrogen pollution prevention or reduction strategy.

Manure and faeces are the main sources of nitrogen pollution on livestock farms. The non-digestible part of the protein taken with the feed, that is, organic nitrogen, is thrown out with manure and feces. In animal feed, feeds with high protein content are generally preferred. However, high protein feeds do not always affect the yield in nonproductive animals. Contrary, indigestible protein increases nitrogen excretion along with manure and feces. Nutrients that cannot be undigested by animals are excreted as urea $\left(\mathrm{CO}\left(\mathrm{NH}_{2}\right)_{2}\right)$ in mammals and as uric acid $\left(\mathrm{C}_{5} \mathrm{H}_{4} \mathrm{O}_{3} \mathrm{~N}_{4}\right)$ in poultry through manure and feces as $\mathrm{N}$ (Yaylı and Kılıç, 2021). The hydrolysis of urea forms ammonia by urease enzymes in an anaerobic environment. Uric acid, on the other hand, is broken down by microorganisms and bacteria to form ammonia.

Failure to properly and planned manure management systems in livestock enterprises causes environmental pollution. Storing the manure without taking the necessary precautions and exposing it to rainwater causes the amount of $\mathrm{N}$ and $\mathrm{K}_{2} \mathrm{O}$ in the manure to decrease. In incorrect storage and manure management systems, the leakage of $\mathrm{N}$ from the manure into the soil causes pollution in the surface and groundwater (Boyac1 et al., 2011).

The most important nitrogen gases emitted by anthropogenic activities are nitrogen oxides $\left(\mathrm{NO}_{\mathrm{x}}\right)$, nitrous oxide $\left(\mathrm{N}_{2} \mathrm{O}\right)$, and ammonia $\left(\mathrm{NH}_{3}\right)$ (Behera et al., 2013). Nitrogen consists of different forms as a result of the microbial breakdown of manure in livestock animals. The main source of reactive nitrogen from manure and feces is the $\mathrm{NH}_{3}$ and $\mathrm{N}_{2} \mathrm{O}$ compounds. Reactive nitrogen can easily be displaced by the nitrogen cycle in air, water and soil. Nitrogen fixation occurs when free nitrogen in the atmosphere is retained by bacteria and transforms into $\mathrm{NH}_{4}$ form that plants can use (Karaşahin, 2014). Nitrification takes place by converting ammonium $\left(\mathrm{NH}_{4}^{+}\right)$to nitrite $\left(\mathrm{NO}_{2}^{-}\right)$by Nitrosomonas bacteria, and nitrite to nitrate $\left(\mathrm{NO}_{3}{ }^{-}\right)$ with Nitrobacter. Nitrite is an intermediate product in nitrification and quickly turns into nitrate form. Denitrification processes take place by reducing nitrate and nitrite and turning them back into elemental nitrogen gas. In the denitrification process, $\mathrm{N}_{2} \mathrm{O}$ is formed by the reduction of nitrate. $\mathrm{N}_{2} \mathrm{O}$ greenhouse gas has a great potential for global warming ( $1 \mathrm{~kg}$ of $\mathrm{N}_{2} \mathrm{O}$ gas is $298 \mathrm{~kg} \mathrm{CO}_{2}$ equivalent).

Some of the ammonia that microorganisms can not use in animals digestive systems is thrown out, and nitrogen loss occurs. Ammonia is a key component in the global nitrogen cycle and plays an important role (Ti et al., 2019; Erisman et al., 2007; Leip et al., 2015; Galloway et al., 2003). Ammonia can contribute to the greenhouse effect by contributing to soil acidification, water eutrophication, biodiversity loss and nitrous oxide formation when it returns to the earth through nitrogen accumulation through the nitrogen cycle (Erisman et al., 2007; Hou and Yu, 2020). Ammonia emissions from livestock farms are also the main source of particulate matter in the atmosphere (Dai et al., 2019). Nitrate $\left(\mathrm{NO}_{3}{ }^{-}\right)$, an important component formed in the nitrogen cycle, causes it to become eutrophic by mixing in water resources. Nitrate, which is an output in livestock production, increases daily as an input in crop production and causes greater pollution, especially in water resources. There is a determining the pollution on the water resources caused by nitrates of agricultural origin and the prevention convenience Regulation on the Protection of Waters against Agricultural Nitrate Pollution in Turkey. According to this regulation, water resources' eutrophication potential containing more than 50 $\mathrm{mg} / \mathrm{L}$ of nitrate is determined (Anonymous, 2016). Also, nitrogen compounds cause toxicological problems in underground and aboveground sources, apart from eutrophication, affecting the oxygen concentration and drinking water (Ardıç, 2013).

In this study, to determine the size of the nitrogen manure amount of pollution caused consisting of animal species from the agricultural sector in Turkey. 


\section{Materials and method}

In this study, taking into account, the animal species in Turkey are intended to estimate the actual size of the nitrogen pollution arising from livestock operations and the determination of the points to be focused on.
Turkey seems a general upward trend in the presence of livestock animals in 2020 (Table 1). With the increasing demand for livestock products, the amount of manure created by the increase in livestock animals' number becomes difficult to manage (Chadwick et al., 2020).

Table 1. Livestock numbers (head/year) (TUIK, 2021)

\begin{tabular}{cccc}
\hline Livestock animals & $\mathbf{2 0 1 9}$ & 2020 & Change (\%) \\
\hline Culture breed cattle & 3793401 & 1245275 & -67.17 \\
Culture hybrid cattle & 3121495 & 1039112 & -66.71 \\
Calf-Heifer (Culture breed) & 1214030 & 1245275 & 2.57 \\
Calf-Heifer (Culture hybrid) & 1043498 & 1039112 & -0.42 \\
Indigenous cow & 664597 & 644800 & -2.98 \\
Bull & 836561 & 958017 & 14.52 \\
Calf-Heifer (indigenous) & 218841 & 213112 & -2.62 \\
Bullock & 14074 & 19775 & 40.51 \\
Laying hen & 120725299 & 121302869 & 0.48 \\
Broiler & 221841860 & 258046340 & 16.32 \\
Turkey & 4541102 & 4797793 & 5.65 \\
Buffalo (female) & 45337 & 45853 & 1.14 \\
Buffalo (male) & 110802 & 117935 & 6.44 \\
Sheep & 37276050 & 42126781 & 13.01 \\
Goat & 11205429 & 11441418 & 2.11 \\
\hline
\end{tabular}

According to animal species, there were obtained from the Pasture Regulation necessary reference values for nitrogen conversion coefficients (Table $2)$. Bovine animal unit (BBHB) is the reference value initially established according to each type of animals nutritional or feed needs. Culture breed dairy cow was taken as a bovine unit. According to regulation, it is taken as a basis that $2.5 \%$ of dry grass or $10 \%$ of green grass will be fed to animals daily live weight (Mera Yönetmeliği, 1998). According to these reference values, animal species average amount of nitrogen excretion per year is given in Table 2. Poultry manure contains higher dry matter $(\mathrm{DM})$ and $\mathrm{N}$, while cattle manure is rich in organic matter $(\mathrm{OM})$ and organic carbon (OC) (Kılıç et al., 2014). The nitrogen pollution per unit of poultry is higher than other livestock animal species. Because in poultry, feeds with high nutritional value are given to produce abundantly in a short time. The non-digestible part is thrown away with the manure, and its nitrogen content is high (İnal et al., 1996; Özdemir and Sezer, 2013; Görmüş, 2018). However, more nitrogen excretion occurs, especially due to the high daily manure amounts of cattle.

Table 2. Annual nitrogen amount consisting of bovine unit values and animal manure by animal species

\begin{tabular}{ccc}
\hline Livestock animals & BBHB conversion coefficient & kg N / yll.BBHB \\
\hline Laying hen & 0.004 & 85 \\
Broiler & 0.0025 & 85 \\
Turkey & 0.02 & 85 \\
Süt sı̆̆ırı & & \\
Culture breed cattle & 1 & 70 \\
Calf-Heifer (Culture breed) & 0.6 & \\
Culture hybrid cattle & 0.75 & \\
Calf-Heifer (Culture hybrid) & 0.45 & 70 \\
Indigenous cow & 0.5 & 70 \\
Calf-Heifer (indigenous) & 0.3 & 70 \\
Sheep & 0.1 & 70 \\
Goat & 0.08 & 70 \\
Buffalo & & \\
Buffalo (male) & 0.9 & \\
Buffalo (female) & 0.75 & \\
Bullock & 0.6 & \\
Bull & 1.5 & \\
\hline
\end{tabular}




\section{Discussion and conclusion}

According to the calculations made, it is seen that the $\mathrm{N}$ excretions of bovine animals and ovine are more than poultry (Table 3). The reason for this is that the daily manure amount of cattle is higher. Daily manure production of dairy cattle is $43 \mathrm{~kg}$, beef cattle $29 \mathrm{~kg}$, sheep $2.40 \mathrm{~kg}$, goat $2.05 \mathrm{~kg}$, broiler $0.19 \mathrm{~kg}$, laying hen $0.13 \mathrm{~kg}$ and turkey 0.38 kg (Yağl1 and Koç, 2019). Nitrogen excretion from livestock was 1062004 tons N/year in 2019 and 834381 tons N/year in 2020. It is observed that this decrease in the rate of nitrogen excretion with fertilizer decreases with the decrease in the number of cattle. It is observed that this decrease in the rate of nitrogen excretion with manure decreases with the decrease in the number of cattle.

Table 3. Nitrogen excretion by livestock animal species (tons/year)

\begin{tabular}{ccc}
\hline Livestock animals & $\mathbf{2 0 1 9}$ & $\mathbf{2 0 2 0}$ \\
\hline Broiler & 47141 & 54835 \\
Laying hen & 41047 & 41243 \\
Turkey & 7720 & 8156 \\
Sheep & 260932 & 294887 \\
Goat & 62750 & 64072 \\
Culture breed cattle & 265538 & 87169 \\
Calf-Heifer (Culture breed) & 50989 & 52302 \\
Culture hybrid cattle & 163878 & 54553 \\
Calf-Heifer (Culture hybrid) & 32870 & 32732 \\
Indigenous cow & 23261 & 22568 \\
Calf-Heifer (indigenous) & 4596 & 4475 \\
Buffalo (male) & 6981 & 7430 \\
Buffalo (female) & 2380 & 2407 \\
Bull & 87839 & 100592 \\
Bullock & 591 & 831 \\
\hline
\end{tabular}

Manure management systems are critical in reducing nitrogen excretion, which increases with the increase in the number of livestock animals. According to Figure 1, it is seen that most of the nitrogen pollution is caused by cattle. Manure, especially in large enterprises and facilities, emerges as a significant problem. Bovine manure contains macro and micronutrients, and stable organic nitrogen in the barn decomposes slowly. Approximately $40-50 \%$ of nitrogen continues to decompose in the first year, $12-15 \%$ in the second year, $5-6 \%$ in the third year and less in other years (Çayır et al., 2012).

Livestock is rich in nitrogen, phosphorus and potassium, which increase crop yield and soil fertility. Beef manure and pig manure have a high moisture content (> 85\%), while poultry, sheep and goats have relatively lower moisture content $(70 \%)$. Solid manure has a higher nutrient density. It is easier to process, transport and use. Therefore, poultry, sheep, and goat manure have higher values than pig and cattle manure ( $\mathrm{Li}, 2020)$.

When nitrogen pollution in poultry was examined, it was observed that more nitrogen was formed in broiler chickens. Because broiler chickens are breeded in litter, they mix as of manure, excrement and litter. Since laying hens are generally cultivated in caged systems without litter, the manure is in pure form without litter (Özdemir and Sezer, 2013).

It is seen that the highest $\mathrm{N}$ load occurs in the Eastern Anatolia region when nitrogen pollution caused by livestock farms is examined by region in 2020 (Table 4). Bovine and ovine livestock breeding is the animal species with the highest nitrogen pollution in the Eastern Anatolia region. There are limited economic activity areas since much cannot be cultivated due to the climatic conditions in this region. It is made mostly in the form of cold-enduring cattle and sheep pasture livestock.

As a result of this study, Turkey's nitrogen pollution potential can be projected for 2021 using the obtained values. According to TUIK's data, livestock animals' numbers showed an average annual increase of $5.1 \%$ in the last 10 years (Table 5). It is seen that there is an increase in all animal species except a bullock. Livestock animal numbers are expected to reach approximately 472 520269 in 2021. 


\section{9}

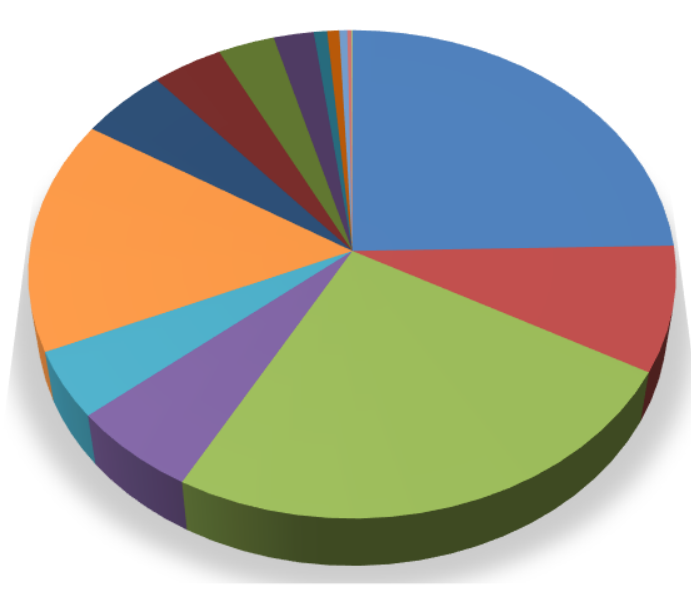

- Sheep

- Bull

- Culture breed cattle

- Goat

- Broiler

Culture hybrid cattle

- Calf-Heifer (Culture breed)

- Laying hen

- Calf-Heifer (Culture hybrid)

- Indigenous cow

- Turkey

- Buffalo (male)

- Calf-Heifer (indigenous)

- Buffalo (female)

Bullock

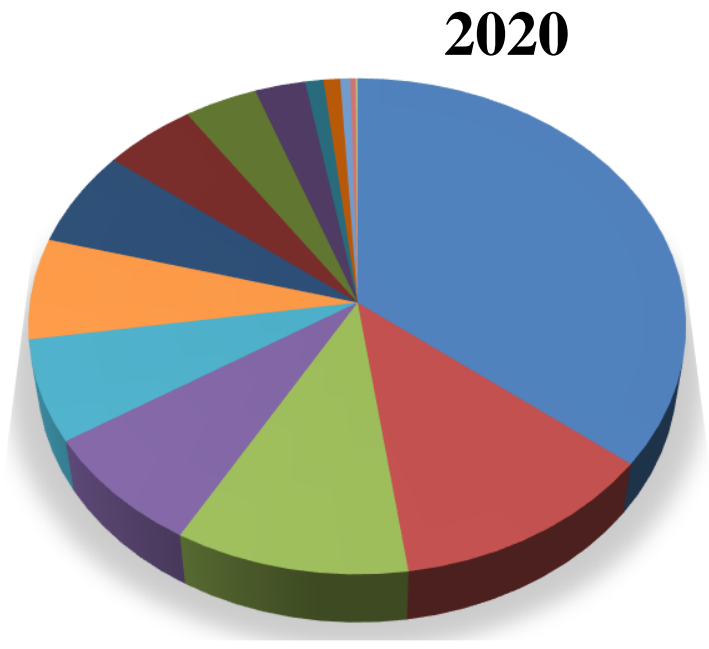

- Sheep

- Bull

Culture breed cattle

- Goat

- Broiler

- Culture hybrid cattle

- Calf-Heifer (Culture breed)

- Laying hen

- Calf-Heifer (Cultur hybrid)

- Indigenous cow

- Turkey

- Buffalo (male)

- Calf-Heifer (indigenous)

- Buffalo (female)

Bullock

Figure 1. Contributions of $\mathrm{N}$ pollution by livestock animal

Table 4. Nitrogen pollution by regions (tons N/year)

\begin{tabular}{cccccccc}
\hline Mediterranean & Aegean & Black Sea & $\begin{array}{c}\text { Southeastern } \\
\text { Anatolia }\end{array}$ & $\begin{array}{c}\text { Marmara } \\
\text { Region }\end{array}$ & $\begin{array}{c}\text { East } \\
\text { Anatolia }\end{array}$ & $\begin{array}{c}\text { Central } \\
\text { Anatolia }\end{array}$ \\
\hline Sheep & 23647 & 31455 & 13980 & 53255 & 34794 & 78043 & 59713 \\
Goat & 18633 & 7594 & 2421 & 16365 & 5358 & 9616 & 7134 \\
Cattle & 33077 & 70529 & 60933 & 39262 & 56065 & 91211 & 81479 \\
Buffalo & 177 & 633 & 3072 & 884 & 2259 & 1326 & 1166 \\
Bullock & 47 & 105 & 884 & 158 & 48 & 111 & 21 \\
Bull & 5475 & 9285 & 10850 & 18032 & 9591 & 26854 & 20505 \\
Laying & 2242 & 14169 & 3311 & 3217 & 7998 & 1699 & 8608 \\
Hen & 6032 & 14913 & 2710 & 136 & 27009 & 1652 & 2383 \\
Broiler & 78 & 3533 & 163 & 624 & 2927 & 586 & 245 \\
Turkey & 89409 & 152214 & 98322 & 131933 & 146050 & 211099 & 181253 \\
Toplam & & & & & &
\end{tabular}

Table 5. Change rate of livestock numbers in the last 10 years

\begin{tabular}{cccccccccc}
\hline Livestock animal & Sheep & Goat & Cattle & Buffalo & Bullock & Bull & Laying Hen & Broiler & Hen \\
\hline Change (\%) & 6.3 & 6.3 & 4.4 & 8.7 & -2.9 & 7.2 & 5.6 & 4.8 & 5.4 \\
\hline
\end{tabular}


As a result of the projection made by predicting that this increase will continue in 2021 , the nitrogen pollution expected to occur according to livestock animal species in 2021 is given in Figure 2. The expected livestock numbers are predicted to cause 1061762 tons N/year nitrogen pollution.

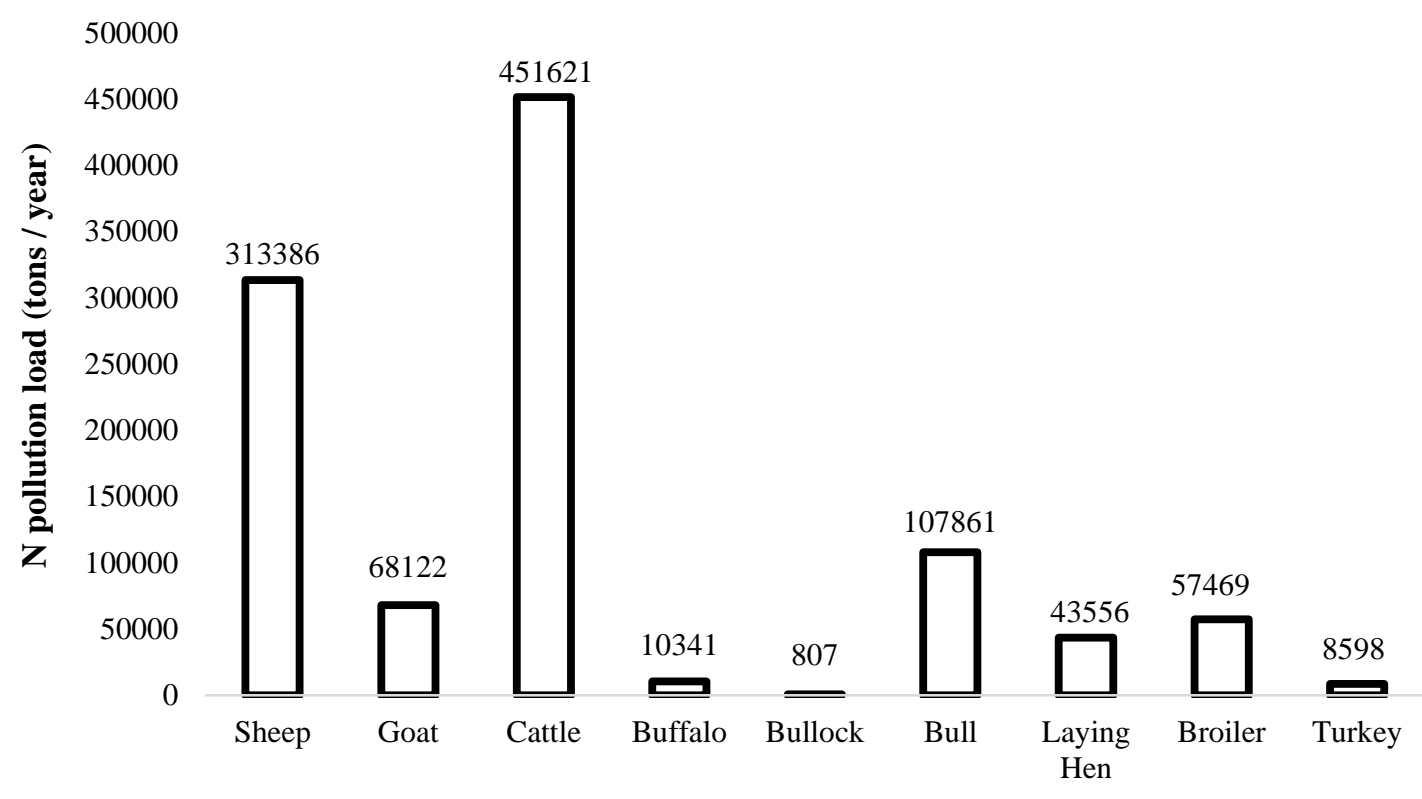

Figure 2. N pollution load projected for 2021 (tons/year)

In this study, the amount of nitrogen pollution discharged with manure from farm animals has been estimated from the general livestock animal numbers. Manure is in on into the atmosphere in the form of nitrogenous compounds by microbial breakdown in intensive livestock facilities. It also causes diffuse pollution by infiltrating ground and surface waters through runoff and leakage from pastures and agricultural lands. According to Turkish Environmental Legislation, livestock farms should be at least $500 \mathrm{~m}$ and an average of $1000 \mathrm{~m}$ away from residential areas. It should be at least $300 \mathrm{~m}$ away from lakes and water sources, at least $100 \mathrm{~m}$ away from irrigation and drainage channels, and at least $30 \mathrm{~m}$ from sanitary installations that provide water (Karaman, 2005; Parlakay et al., 2015; Yüksel and Şişman, 2015). Manure contains large amounts of $\mathrm{N}$ in organic form and is converted to inorganic form by mineralization, posing a serious risk to the environment. Manure is applied to the soil by spreading it once, so compared to chemical fertilizer, the $\mathrm{N}$ content is more mixed into ground and surface waters (Soyer and Y1lmaz, 2020). Nitrogen excretion rates may vary according to the practices in the enterprises, the age, gender, breed, yield, and ration composition of the livestocks. There is needed an integrated approach to reduce the formation of reactive nitrogen due to the gradual formation of nitrogen from agricultural systems and areas with intensive agriculture. In manure management practices, improvement studies should be carried out at all stages such as housing, storage of manure, processing and application to the field. Manure storage areas and silos bottom must be well insulated so that manure does not leach with ground and surface waters. Directing the manure from animal production to biogas production will not only provide energy gain but also have positive environmental effects (Kayişoğlu and Göncü, 2020). Thus, considering that it will effectively reduce nitrogen emissions by converting the methane gas content of the manure into energy, it is thought to be one of the effective methods.

\section{References}

Anonymous, (2016). T.C. Tarım ve Orman Bakanlığı. (2021, 22 March) Retrieved from https://www.tarimorman.gov.tr/Belgeler/Mevzu at/Yonetmelikler/tarimsal_kaynakli_\%20nitratki rliligine_karsi.pdf.

Ardıç, C. (2013). İ̧̧me suyundaki nitrat konsantrasyonunun insan sağllğ oluşturduğu risklerin belirlenmesi. Yüksek Lisans Tezi, Hacettepe Üniversitesi, Ankara.

Behera, S.N., Sharma, M., Aneja, V.P. and Balasubramanian, R. (2013). Ammonia in the atmosphere: a review on emission sources, atmospheric chemistry and deposition on terrestrial bodies. Environmental Science and Pollution Research, 20(11), 8092-8131. https://doi.org/10.1007/s11356-013-2051-9 
Boyac1, S., Akyüz, A. ve Kükürtçü, M. (2011). Büyükbaş hayvan barınaklarında gübrenin yarattığı çevre kirliliği ve çözüm olanakları. Tarım Bilimleri Araștırma Dergisi, 4(1), 49-55.

Chadwick, D.R., Williams, J.R., Lu, Y., Ma, L., Bai, Z., Hou, Y., Chen, X. and Misselbrook, T.H. (2020). Strategies to reduce nutrient pollution from manure management in China. Frontiers in Agricultural Science and Engineering, 7(1), 4555. https://doi.org/10.15302/J-FASE-2019293

Çayır, M., Atılgan, A. ve Hasan, Ö.Z. (2012). Büyükbaş hayvan barınaklarındaki gübrelikler ve su kaynaklarına olan durumlarının incelenmesi. Süleyman Demirel Üniversitesi Ziraat Fakültesi Dergisi, 7(2), 1-9.

Dai, C., Huang, S., Zhou, Y., Xu, B., Peng, H., Qin, P. and $\mathrm{Wu}, \mathrm{G}$. (2019). Concentrations and emissions of particulate matter and ammonia from extensive livestock farm in South China. Environmental Science and Pollution Research, 26(2), 1871-1879. https://doi.org/10.1007/s11356-018-3766-4

Erisman, J. W., Bleeker, A., Galloway, J. and Sutton, M. S. (2007). Reduced nitrogen in ecology and the environment. Environmental Pollution, 150(1), 140-149.

https://doi.org/10.1016/j.envpol.2007.06.033

Galloway, J. N., Aber, J. D., Erisman, J. W., Seitzinger, S. P., Howarth, R. W., Cowling, E. B. and Cosby, B. J. (2003). The nitrogen cascade. Bioscience, 53(4), 341-356. https://doi.org/10.1641/00063568(2003)053[0341:TNC]2.0.CO;2

Görmüş, C. (2018). Türkiye'deki hayvan gübrelerinin biyogaz enerji potansiyelinin belirlenmesi. Yüksek Lisans Tezi, Namık Kemal Üniversitesi, Tekirdağ.

Günal, M. (2019). Süt sığırı yetiştiriciliği kaynaklı azot kirliliği. Mustafa Kemal Üniversitesi Tarım Bilimleri Dergisi, 24(2), 153-164.

Hou, X. and Yu, X. (2020). An ammonia emissions inventory for agricultural sources in Hefei, China. Atmospheric and Oceanic Science Letters, $\quad$ 13(3), 260-267. https://doi.org/10.1080/16742834.2020.1747355

İnal, A., Sözüdoğru, S. ve Erden, D. (1996). Tavuk gübresinin içeriği ve gübre değeri. Tarım Bilimleri Dergisi, 2(3),45-50.

Karaman, S. (2005). Tokat yöresinde hayvan barınaklarından kaynaklanan çevre kirliliği ve çözüm olanakları. Gaziosmanpaşa Üniversitesi Ziraat Fakültesi Dergisi, 22(2), 57-65.

Karaşahin, M. (2014). Bitkisel üretimde azot alım etkinliği ve reaktif azotun çevre üzerine olumsuz etkileri. Akademik Platform Mühendislik ve Fen Bilimleri Dergisi, 2(3), 15-21. https://doi.org/10.5505/apjes.2014.38247

Kayişoğlu, B. and Göncü, S. (2020). Determination of commercially available biogas production capacity and effects on methane capture in Tekirdağ province. Tekirdağ Ziraat Fakültesi Dergisi, 17(3), 445-455. https://doi.org/10.33462/jotaf.730915

Kılıç, İ., Uğuz, S. and Aşık, B.B. (2014). Soil pollution by trace metals derived from animal feed and manure in the Bursa region of Turkey. Toxicological \& Environmental Chemistry, 96(10), 1476-1488. https://doi.org/10.1080/02772248.2015.1029927

Leip, A., Billen, G., Garnier, J., Grizzetti, B., Lassaletta, L., Reis, S., Simpson, D., Sutton, M. A., Vries, W, Weiss, F. and Westhoek, H. (2015). Impacts of European livestock production: nitrogen, sulphur, phosphorus and greenhouse gas emissions, land-use, water eutrophication and biodiversity. Environmental Research Letters, 10(11), 115004. http://dx.doi.org/10.1088/17489326/10/11/115004

Li, J. (2020). Engineering informatics and systems modeling for optimization of animal manure management. Doctoral dissertation, University of Illinois at Urbana-Champaign.

Mera Yönetmeliği, (1998). Mera Yönetmeliği, Uygulama Esaslar1. (2021, 26 March). Retrieved from https://www.mevzuat.gov.tr/mevzuat?Mevzuat No=5057\&MevzuatTur=7\&MevzuatTertip=5.

Özdemir, S. ve Sezer, B. (2013). Kümes atıklarının organik gübre ve biyo-yakıt olarak değerlendirilmesi. Tavukçuluk Araştırma Dergisi, 10, 20-24.

Parlakay, O., Çelik, A. ve Kızıltuğ, T. (2015). Hatay ilinde tarımsal üretimden kaynaklanan çevre sorunları ve çözüm önerileri. Mustafa Kemal Üniversitesi Ziraat Fakültesi Dergisi, 20(2), 1726.

Soyer, G. and Yilmaz, E. (2020). Waste management in dairy cattle farms in Aydın region. Potential of Energy Application. Sustainability, 12(4), 1614. https://doi.org/10.3390/su12041614

Ti, C., Xia, L., Chang, S. X. and Yan, X. (2019). Potential for mitigating global agricultural ammonia emission: a meta-analysis. Environmental Pollution, 245, 141-148. https://doi.org/10.1016/j.envpol.2018.10.124

TUIK, (2021). Türkiye İstatistik Kurumu, Hayvancılık istatistikleri. (2021, 26 February) Retrieved from 
https://biruni.tuik.gov.tr/medas/?kn=101\&locale $=\operatorname{tr}$

Yağlı, H. ve Koç, Y. (2019). Hayvan gübresinden biyogaz üretim potansiyelinin belirlenmesi: Adana ili örnek hesaplama. Çukurova Üniversitesi Mühendislik-Mimarlı Fakültesi Dergisi, 34(3), 35-48. https://doi.org/10.21605/cukurovaummfd.63760 3
Yaylı, B. and Kılıç, İ. (2021). Mitigation of ammonia from litter by additives in poultry houses. Kavak, D. (Ed.), Current Engineering Sciences Research, (p 103-118). Livre de Lyon.

Yüksel, A. H. ve Şişman, C. B. (2015). Hayvan barınaklarının planlanmast. İstanbul: Hasad Yayıncılık LTD. ŞTİ. 